\title{
Determination of Coastal Belt in the Disaster Prone Area: A case study in the Coastal area of Bantul Regency, Yogyakarta, Indonesia
}

\author{
Arief Widianto, Michiel Damen
}

Received: 11082014 / Accepted: 25082014 / Published online: 31122014

(c) 2014 Faculty of Geography UGM and The Indonesian Geographers Association

\begin{abstract}
Mitigation strategy development is needed for protecting coastal communities and preserving coastal resources from the impact of coastal hazards. It is believed that coastal land use planning can be proposed to reduce impact of coastal hazards. The coastal belt boundary development is one of the mitigation approach which is common use in many countries as an inexpensive solution compared to hard structure development. Our study was located in the coastal area of Bantul regency, a low lying coastal area and densely populated region, where some clustered people lives proximity to the sea. In this study, a new method for determining coastal belt boundary was developed in the study area. The Spatial Multi Criteria Evaluation (SMCE) tool of Ilwis plays as powerful tool for assessing coastal vulnerability in term of multihazard events. To calculate the width of the coastal belt boundary, the Ilwis-SMCE outcomes were employed. By applying this method, there were three scenarios of the setbacks wide for both direct and pairwise method to be proposed. In general, the coastal area of Bantul Regency is dominated by high vulnerable area respectively impacted by multi-hazard events (tsunami, high wave and erosion-accretion), by incorporating some coastal features, such as topography, biophysics, economic, and social-culture. The results of the analysis are consistent with what was observed in the actual areas. Taken into account for hazard and vulnerability indices, the coastal belt boundary established in this area should wider than those already determined by existing regulations.
\end{abstract}

Keywords: Coastal belt, spatial multi criteria evaluation (SMCE), Bantul Regency

Abstrak penyusunan strategi mitigasi diperlukan untuk melindungi masyarakat pesisir dan melestarikan sumber daya pesisir dari dampak bahaya pesisir. Perencanaan penggunaan lahan daerah pesisir dapat diusulkan untuk mengurangi dampak bahaya pesisir. Pengembangan batas sempadan pantai merupakan salah satu pendekatan mitigasi yang umum digunakan di banyak negara sebagai solusi murah dibandingkan dengan pembangunan struktur fisik. Penelitian ini terletak di daerah pesisir Kabupaten Bantul, yang merupakan dataran daerah pantai yang rendah dan merupakan daerah padat penduduk, dimana masyarakat secara mengelompok hidup dekat dengan laut. Dalam penelitian ini, metode baru untuk menentukan batas sempadan pantai dikembangkan di daerah penelitian. Spatial Multi Criteria Evaluation (SMCE) pada ILWIS digunakan untuk menilai kerentanan pesisir dalam analisis multi-bencana. Untuk menghitung lebar batas garis pantai, digunakan hasil ILWIS-SMCE. Dengan menerapkan metode ini, ada tiga skenario kemunduran garis pantai untuk kedua metode langsung dan berpasangan yang akan diusulkan. Secara umum, wilayah pesisir Kabupaten Bantul didominasi oleh daerah kerentanan tinggi yang masing-masing dipengaruhi oleh peristiwa multibencana (tsunami, gelombang tinggi dan erosi-akresi), dengan memasukkan beberapa fitur pesisir, seperti topografi, bio-fisika, ekonomi, dan sosial-budaya. Hasil analisis tersebut konsisten dengan apa yang diamati di lapangan. Hasil perhitungan menunujukan untuk bahaya dan indeks kerentanan, batas garis pantai yang didirikan di daerah ini harus lebih luas daripada yang sudah ditentukan oleh peraturan yang ada.

Kata kunci: Kawasan sempadan pantai, spatial multi criteria evaluation (SMCE), Kabupaten Bantul

\section{Introduction}

The southern coast of Java Island is a part of [2009] states that "zoning is an important management the Indonesia archipelago that faces directly to the tool in Integrated Coastal Management (ICM) and subduction zone in the Indian Ocean. Collision buffer zones can be created as transition area between between the India-Australian and Eurasian Plate different landuses and to prevent landuse conflicts". results in endogenic activitis cause the southern coast In coastal regions, coastal belt boundary can be of Java Island being very dynamic and very common developed in order to protect physical development earthquake events (Figure 1). near the coastlines from hazards [Katsanevakis et al.,

In reducing impacts of coastal hazards, it is believed 2011]. By incorporating hazards, vulnerability and risk that coastal land use planning can be proposed. Wong information, the risk based spatial plan can ensure a

Arief Widianto

Ministry of Maritime and Fisheries Affairs

email: arief.widodo@gmail.com

Michiel Damen

International Institute for Geo-Information and Earth Observation, Encshede save and sustainable approach [Hizbaron et al., 2012]. Moreover by minimizing the exposure of people, socioeconomic activities and infrastructures to natural disasters [Sutanta et al., 2012].

Coastal belt boundary development is one of the mitigation strategy applied for protecting coastal 
communities and preserving coastal resources from the impact of coastal hazards. It is also an approach suggested by the Protocol on Integrated Coastal Zone Management of the Barcelona Convention on 24 of March 2011 [Sanò et al., 2011] and generally accepted to be an inexpensive solution if be compared with hard structure development [Linham \& Nicholls, 2010]. To calculate coastal setback lines, the use of physical coastal features are common in some countries, for instance Canada, Barbados, Aruba, Antigua, Sri Lanka, USA, Australia, Denmark, Germany, Norway, Finland, Poland, Spain, Sweden and Turkey [Linham \& Nicholls, 2010].

In this research, a new method for determining coastal belt boundary was developed by applying the coastal vulnerability outcomes of the Spatial Multi Criteria Evaluation (SMCE) tool in Ilwis software. Ilwis is an acronym for the Integrated Land and Water Information System. It is a non-commercial software for Geographic Information System (GIS) with image processing capabilities [Westen, 2009]. Ilwis has been developed by the International Institute for GeoInformation Science and Earth Observation (ITC), Enschede, The Netherlands. Moreover, the SMCE is known as a technique that assists stakeholders in decision making with respect to a particular goal.

A low lying coastal area, the coastal area of Bantul is threatened by multi-hazards [Mardiatno et al., 2009]. It is mainly affected by high waves, coastal erosion-accretion as well as tsunami, the coastal area of Bantul regency was selected for this research. Total area is about $506.85 \mathrm{~km}^{2}$, divided into 3 (three) regent assistance areas, 17 sub-districts, 75 villages and 933 hamlets. Geographically, Bantul regency lies between $07^{\circ} 4404-08^{\circ} 00^{\prime} 27^{\prime \prime} \mathrm{S}$ and $110^{\circ} 1234^{\prime \prime}-110^{\circ} 31^{\prime} 98^{\prime \prime}$ E (Figure 2). Administratively, the study area located among some regencies, such as Sleman is in northern side, Kulonprogo is in western side and Gunung Kidul is in eastern side. While, in southern side is facing directly to the Indian Ocean. The coastal area of Bantul regency, which has about $17 \mathrm{~km}$ of coastlines, consist of three sub-districts, i.e. Srandakan, Sanden and Kretek, includes 11 villages and inhabited by 84,353 people ] [BPS, 2012].

\section{The Methods}

This research aims to develop a method by using Spatial Multi Criteria Evaluation (SMCE) outcomes for determining the coastal belt boundary, which is a predescribed distance in which coastal processes such as hazards should be taken into account, mapped from multi-temporal aerospace images, office data, fieldwork and procedure defined by stakeholders in the coastal area of Bantul Regency.

There were four main activities employed in this research, namely the coastal variables definition and setbacks calculation method, the coastal hazard identification, data collection-processing and data analysis (Figure 3).

The definition coastal features to be used for reconstucting the coastal belt boundary wide was developed by using literatures study, existing regulation analyis and the questionnaires survey to obtain stakeholders opinions. Previous research and regulations was analyzed to determine coastal features to be incorporated for further calculating the setbacks wide, while the SMCE prochedures, weighting strategy applied and the setbacks calculation method was developed by using stakeholders opinion.

There were three main hazards identified in the coastal area of Bantul, i.e high waves, coastal erosionaccretion and tsunami. The coastal vulnerability in relation with these coastal hazards were reconstructed by applying multi level input data (macro and micro scale), multi hazards, and multi weighting stategies in the Ilwis SMCE. Coastal parameters, criteria and its
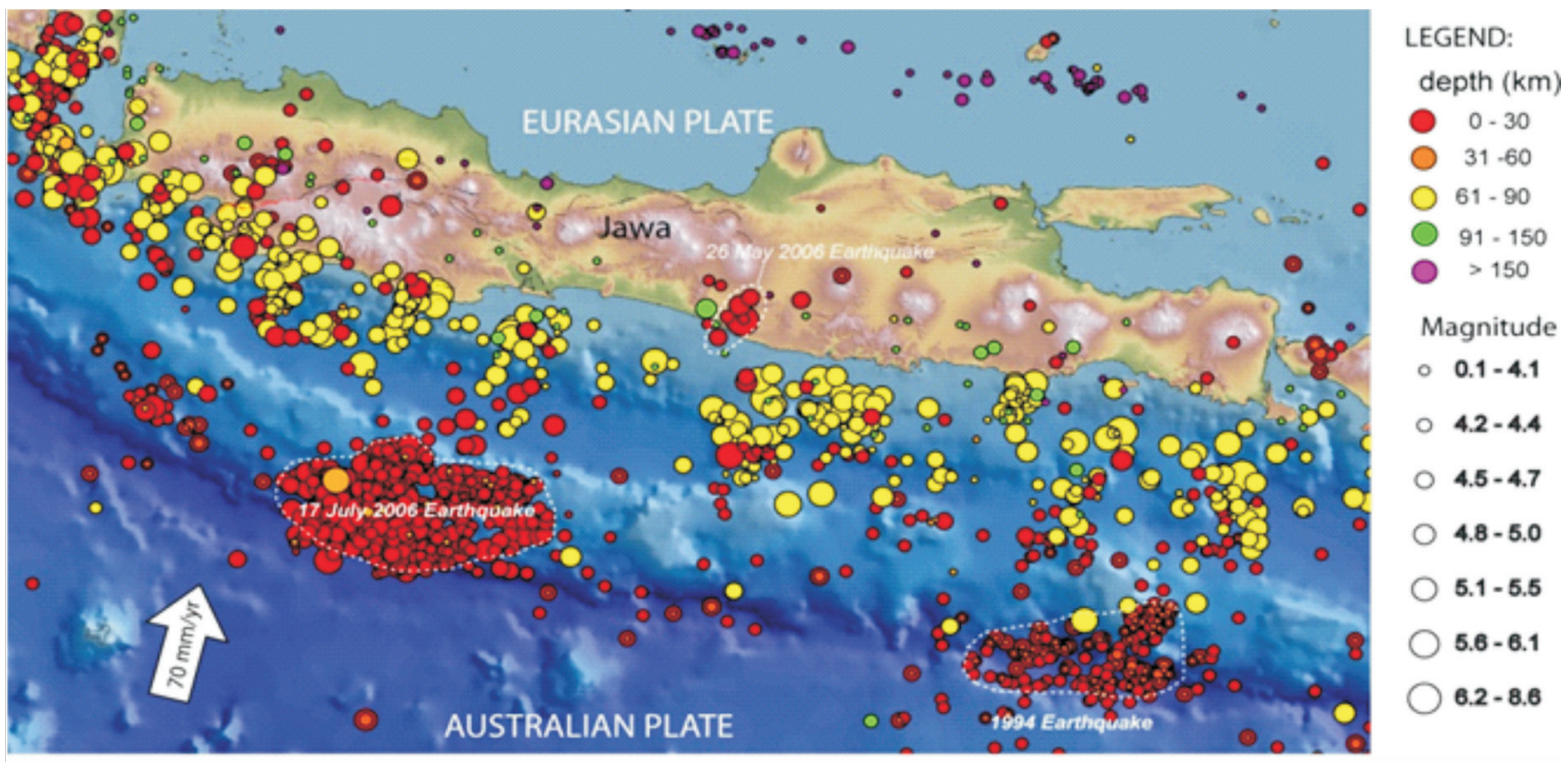

Figure 1. The Potential of Earthquakes in the Southern Coast of Java Island [Kongko, 2012] 


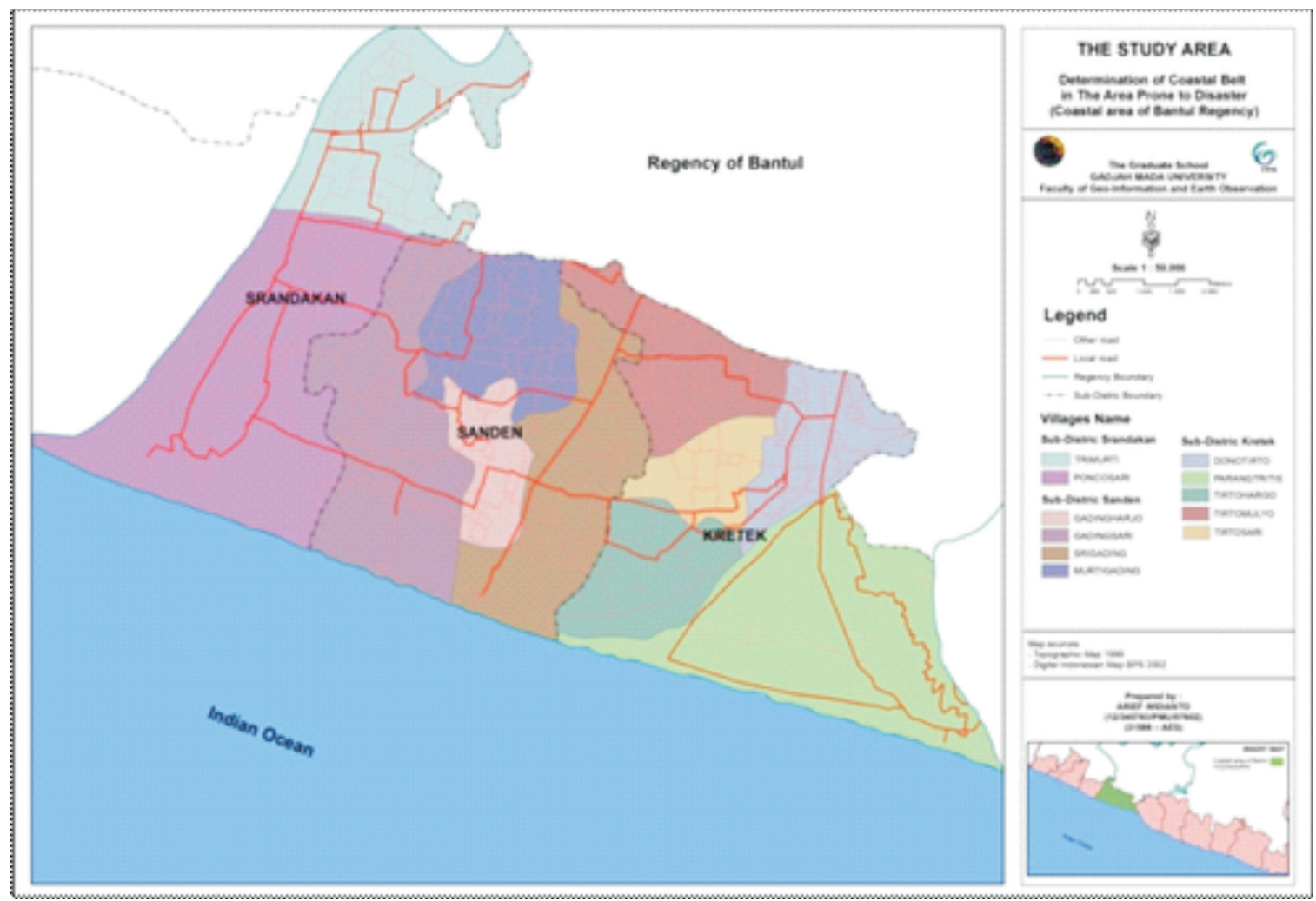

Figure 2. The Study Area - Coastal Area of Bantul Regency

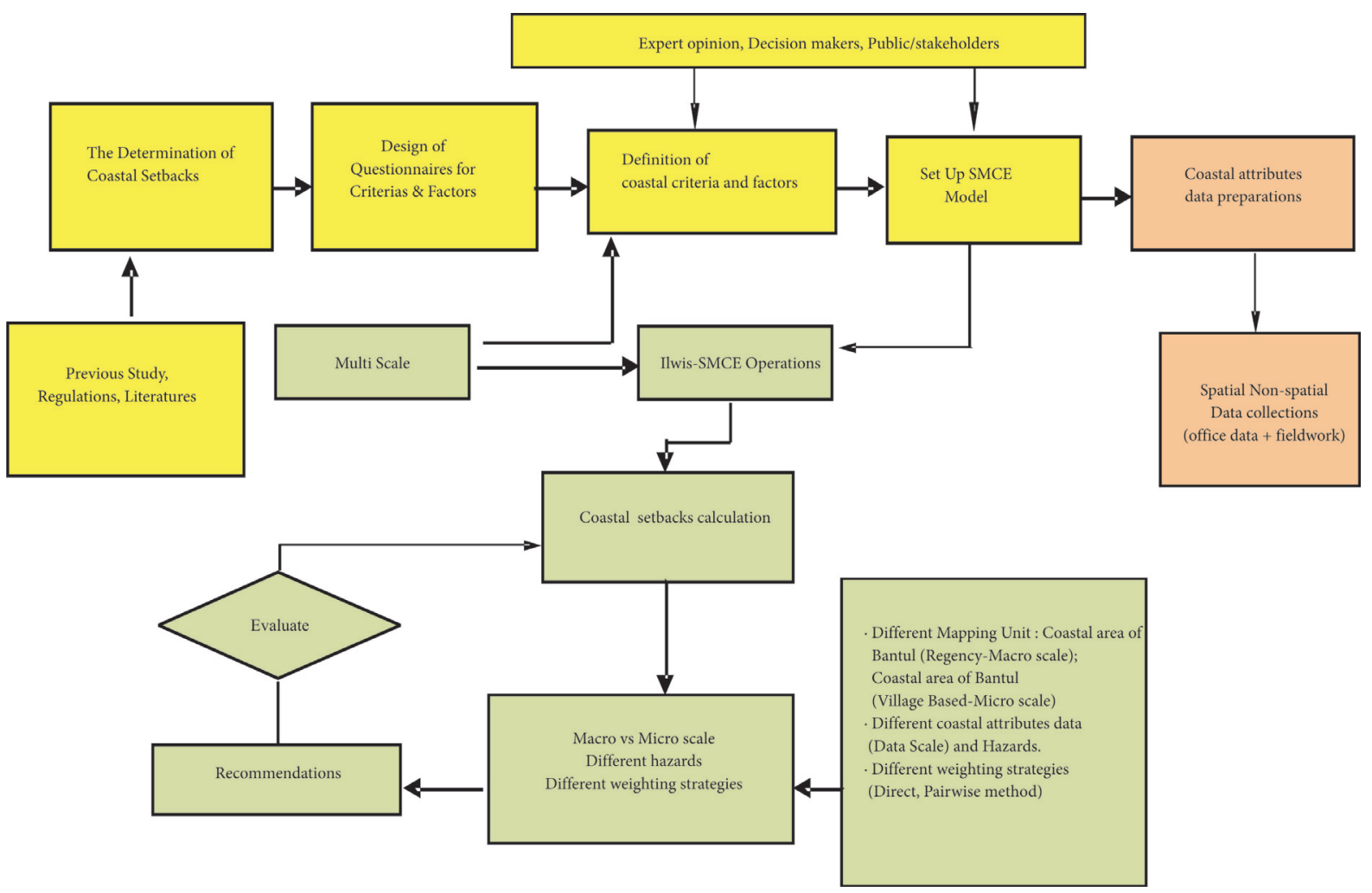

Figure 3. The General Research Methodology 
indicator for detecting the level of coastal vulnerability were defined based on literatures and existing regulations. For instance, the coastal variables selected for assessing tsunami vulnerability, i.e topographic elevation, slope, coastal vegetation cover, coastal morphology, elevation of sand dunes or beach ridge as well as hazard characteristics.

Furthermore, the coastal setbacks wide were reconstucted by applying the Ilwis-SMCE outcomes derived from the coastal vulnerability assessment. There were some proposed scenarios of the setbacks wide for both macro and micro scale in the coastal area of Bantul regency.

In this study, there were 3 (three) main hazards identified in the coastal area of Bantul regency, namely tsunami, erosion-accretion and high wave. In this study, tsunami inundation area was delineated from tsunami hazard map year 2012 published by BIG (Agency for Information and Geo-Spatial) as given in Figure 4. Coastal erosion-accretion hazards determined by using multi temporal remote sensely data analysis within about 20 years (1993-2012). While, high waves hazard was reconstucted by using p-GIS survey in the coastal area of Bantul.

The coastal erosion and accretion hazard was reconstructed by assessing the shoreline change and changes rate. In this stage, a short-term shoreline change and changes rate for this study were calculated by using DSAS version 4.2, a freely extension ArcGIS tool developed by the USGS [Thieler, 2009].
There were some spatial and non-spatial data incorporated, such as multi temporal images data and the tides information. The shoreline changes and change rates were assessed by mapping the position of consistent natural shoreline features in past 20 years (1993-2012), by using orthophotos year 1993 and 2000; small format photo year 2006, google image year 2011 and Worldview images year 2012 .

Moreover, transect baselines were generated landward and parallel to general orientation of the shoreline. The cast transects were regularly created at a spacing of $50 \mathrm{~m}$ along the approximately $14.5 \mathrm{~km}$ long stretch of the Bantul coastal area. Based on this baseline, there were 292 transects built along the beach in the coastal area of Bantul regency.

In this study, the average changes rate based on linear regression method employed by DSAS and its distribution along the Bantul coastal area is depicted in Figure 5. Linear regression erosion rate with average at $1.4 \mathrm{~m} /$ year counted in eastern coastal area from Parangtritis to Depok Beach and $0.9 \mathrm{~m} /$ year in around Lagoon Opak River. While, for western coastal area from Samas to Pandansimo was predicted with shorttime linear regression erosion rate by approximately $2.3 \mathrm{~m} /$ year.

To identify high waves hazard, a p-GIS (participatory geographic information system) mapping with community was involved in this research. High wave events on 19-20 September 2013 was used as basis information to be identified for developing the

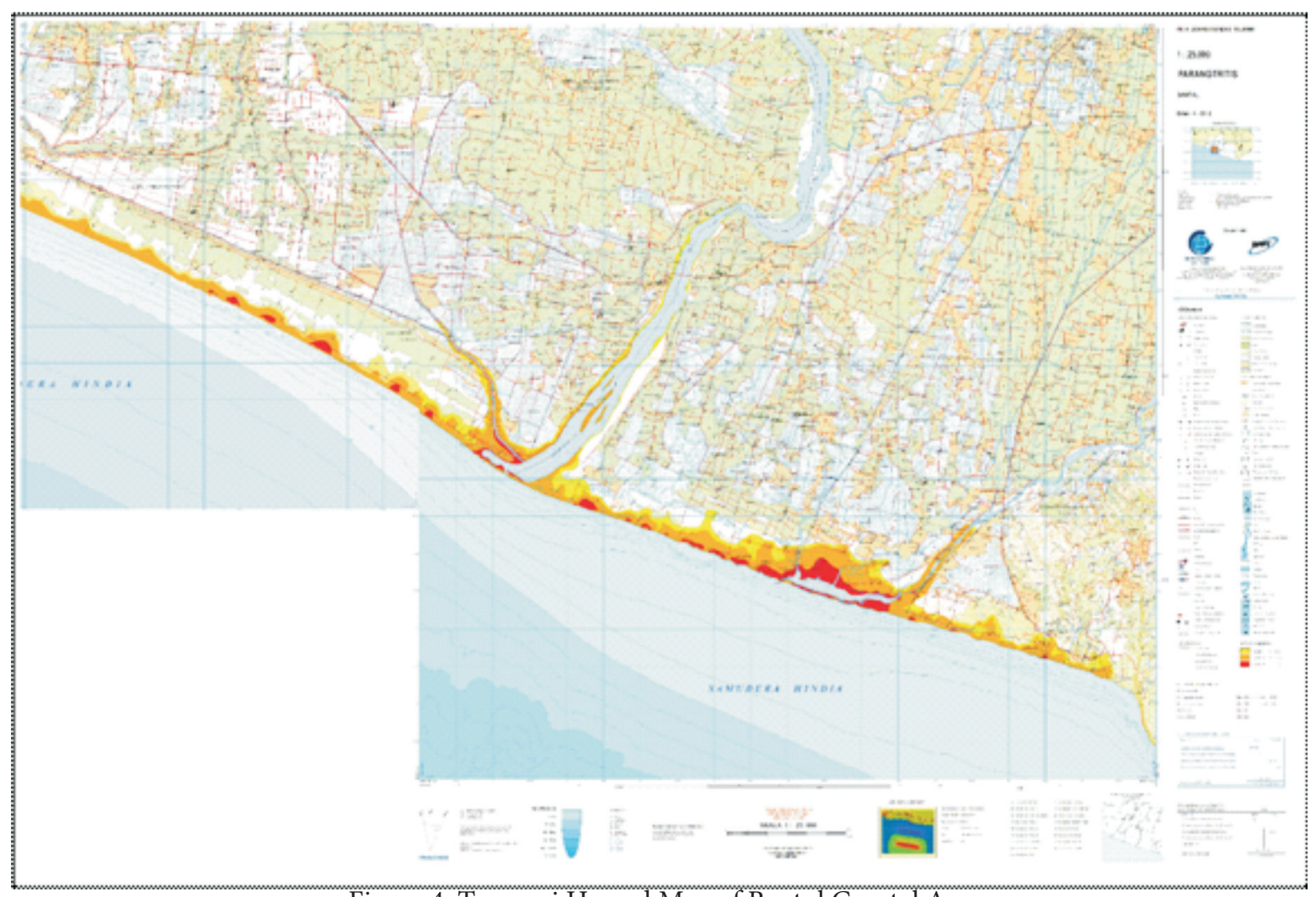

Figure 4. Tsunami Hazard Map of Bantul Coastal Area 
high waves hazard extend map.

With $500 \mathrm{~m}$ of spacing along the Bantul coastline, there were about 25 sample points designed to conduct p-GIS survey. Some coastal users (fishermans, search and rescue guards, restaurant owners and local government officers) were interviewed for the high waves hazard identification (Figure 6 and Figure 7).

There were two sets of geo-spatial data were developed in determining the coastal belt boundary wide for macro and micro scale. In macro scale, the study area focussed on administrative boundary of Bantul Sub-District as mapping unit. In macro scale, the study area consist of 3 (three) coastal sub-districts, namely Kretek, Sanden and Srandakan.

For this purpose, some geo-spatial variables were collected and analyzed, such as topographic elevation, slope, coastal vegetation cover, coastal morphology, elevation of sand dunes or beach ridge as well as hazard characteristics (Figure 8). These data were collected, analyzed and stored in Ilwis software for assessing coastal vulnerability in term of high waves, erosionaccretion and tsunami hazard.

Sanden Sub-District was selected for the coastal belt determination in micro scal. Sanden coastal region was chosen because of its condition as the most vulnerable area impacted by the predicted tsunami hazard, affected by the high wave hazard as well as threatened by coastal retreating.

Sanden Sub-district consisting of 4 (four) villages, namely Gadingsari, Murtigading, Srigading and Gadingharjo. In this stage, some coastal features were improved, such as landuse information, more detail of population data (coastal villages based), and economic related data (Figure 9). These features were collected and furher analyzed in the Ilwis-SMCE in relation with the coastal vulnerability assessment.

The coastal variables data were analyzed in the Iiwis SMCE to assess coastal vulnerability (macro and micro scale) in term of multi hazard events. In the SMCE tool, the coastal vulnerability of high waves, erosion-accretion and tsunami involved some coastal variables defined from literatures, regulations and data availability. Moreover, these data were grouped into 5 groups respectively, such as topography, bio-physics, economic, social-culture and other. Then, the weighting strategy applied using weigh values obtained from stakeholders opinion in the questionnaires survey.

In this study, the higher vulnerability coastal area is the wider the coastal belt wide. By using this scenario, the width of the coastal belt boundary was reconstructed by using the Ilwis-SMCE vulnerability outcomes. So therefore, the setbacks boundary wide were developed in three scenarios, namely ideal, moderate and worse which is established by using the vulnerability values generated from Ilwis-SMCE output histogram.

\section{Result and Discussion}

In the Ilwis-SMCE tool, the problem definition structured in to a criteria tree, with several groups and a number of factors and /or constraints. Figure 10 gives an overview of the goal, sub-goals, groups and criterion/ indicators applied to define vulnerability condition in the coastal area of Bantul regions, for both macro and micro scale of planning.

The coastal vulnerability indices by considering defined coastal variables of multi-hazard events and

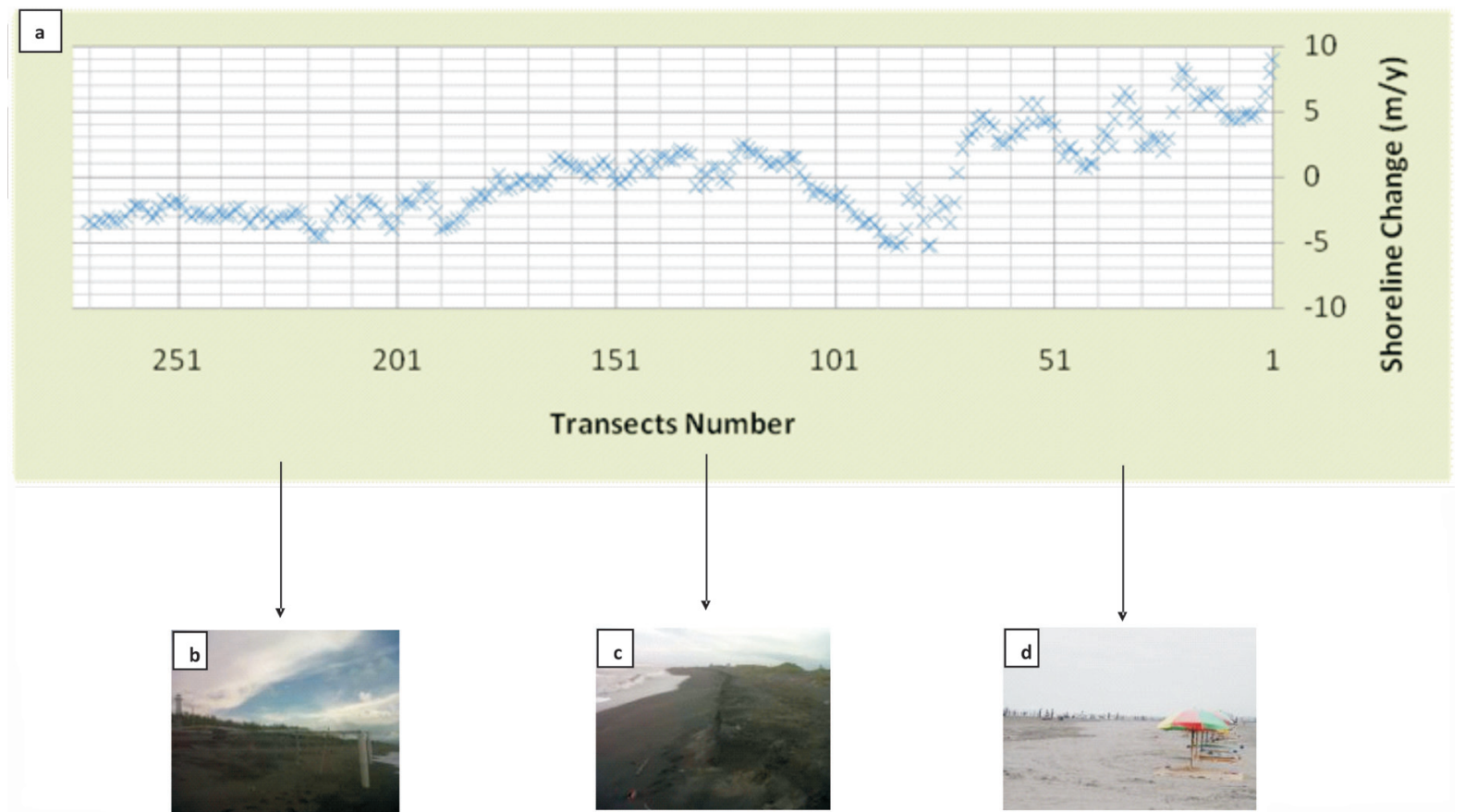

Figure 5. Linear 3egression 3ate from Parangtritis to Pandansimo beach (a); High \&rosion $\$$ aused " rtificial 8 ater 4prings 4hifter from - and to 4hore (c); Retreating $\exists$ and in Eastern \$oast " round Depok \#each (d) and " dvancing 5rends at Parangtritis (e). 


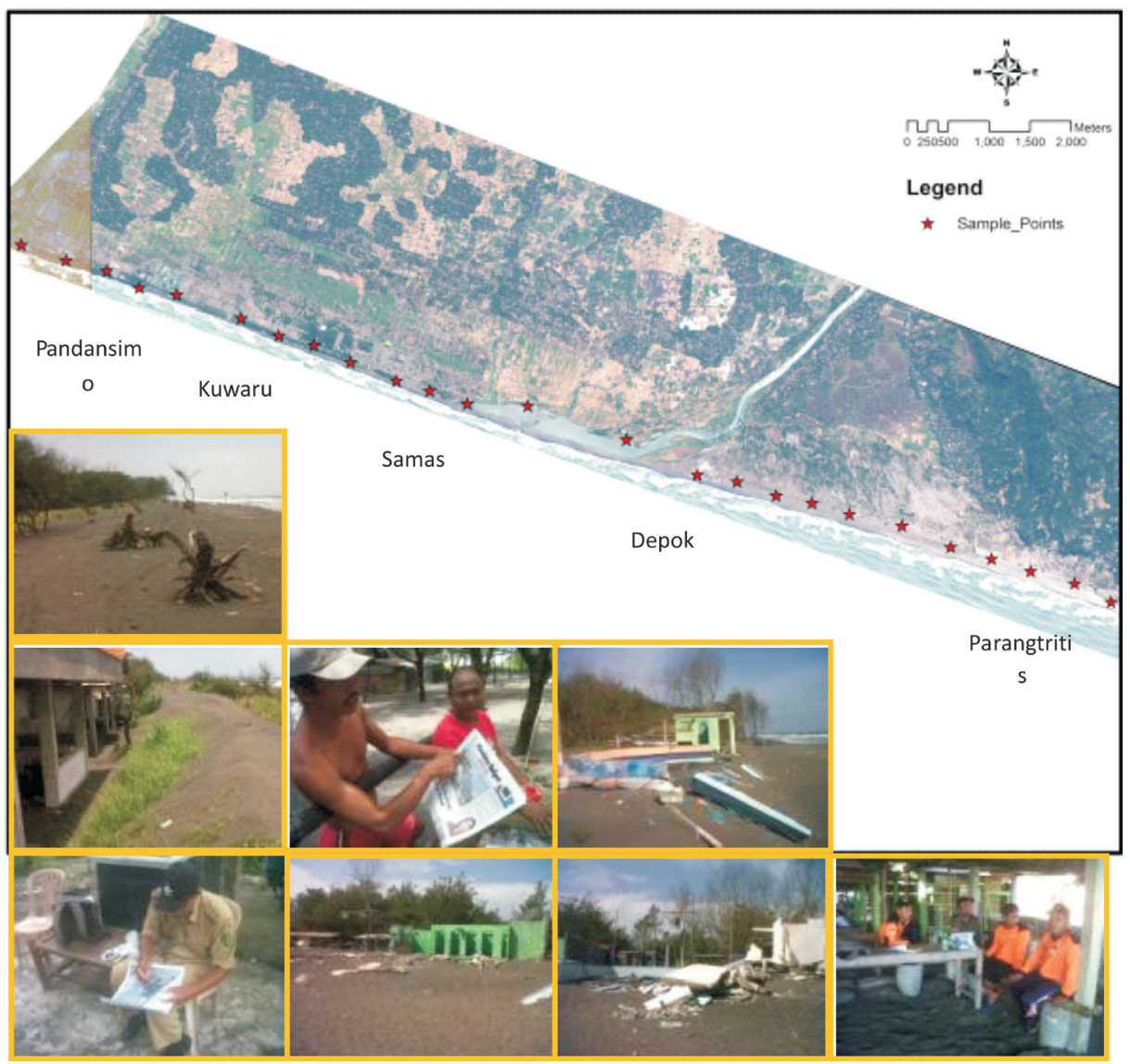

Figure 6. p-GIS Mapping for High Wave Hazard Identification in the Coastal Area of Bantul Regency

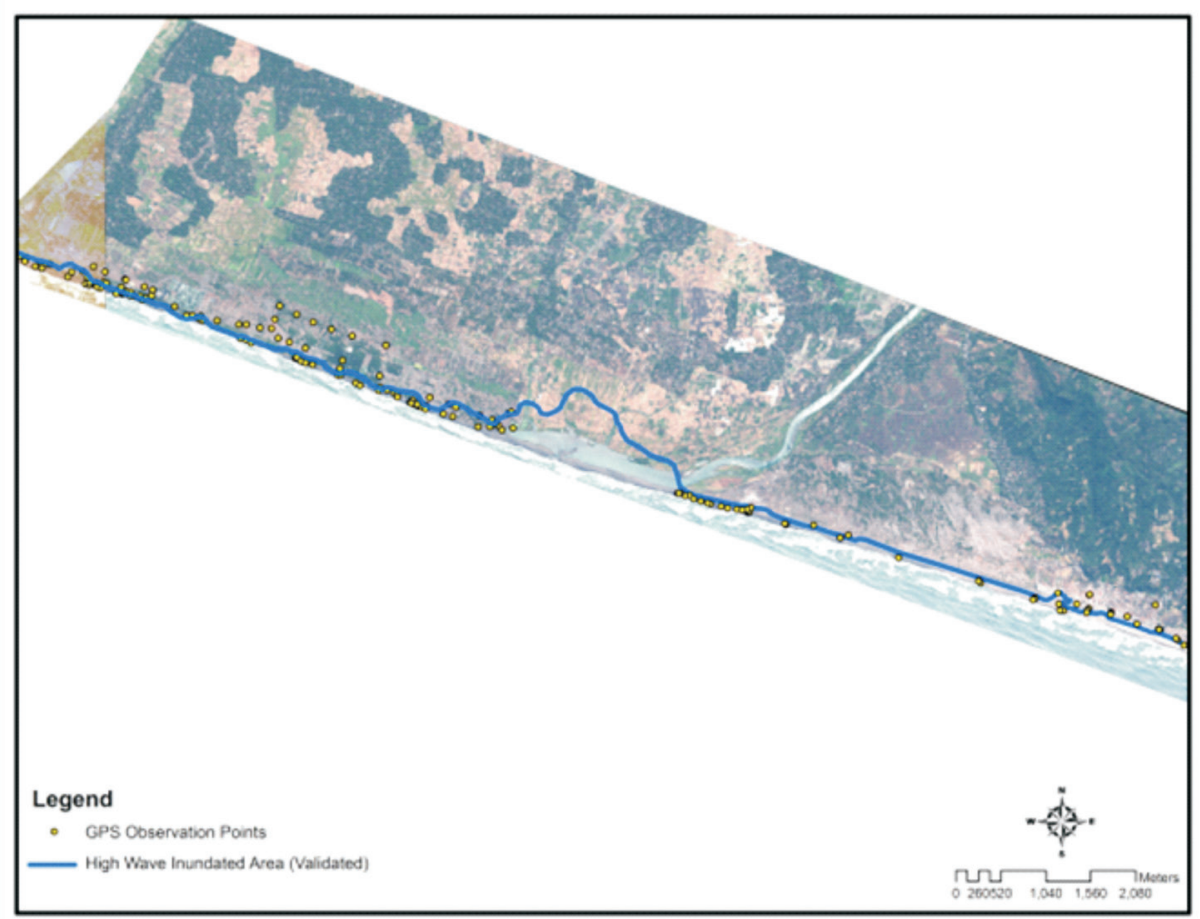

Figure 7. The High Waves Hazard Identified by Using p-GIS Mapping Method 
multi-weighting scenarios developed for the coastal area of Bantul Regency is given in Figure 11 and Table 1. By using multi-weighting strategy, the level of coastal vulnerability for the coastal area of Bantul regency ranges from $0.20-0.79$ (direct) and $0.16-0.83$ (pairwise).

Moreover, in macro scale, the coastal vulnerability indices of Bantul consist of three classes, from very highly to moderate vulnerable (Figure 12). Because the use of administrative based of input data in the Ilwis-
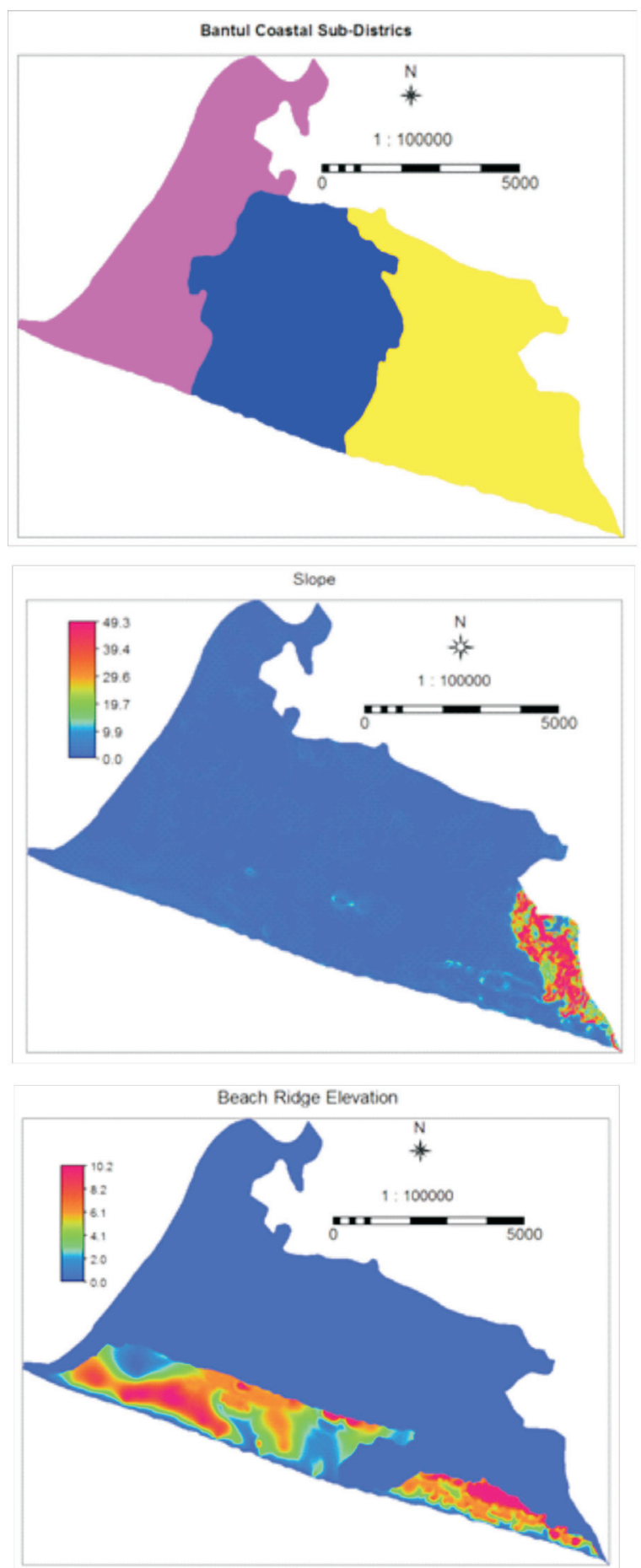

SMCE, it shows that dominant vulnerability values of highly vulnerable (light red color). Some area, with higher elevation, was moderately vulnerable (blue color), and the area mainly proximity to the sea (and river) is very highly vulnerable (light blue color).

By using the coastal vulnerability indices, the setbacks boundary lines were developed for macro scale of Bantul regency. The minimum vulnerability value was used to reconstruct worse scenario of the setbacks, the average value for moderate setbacks and
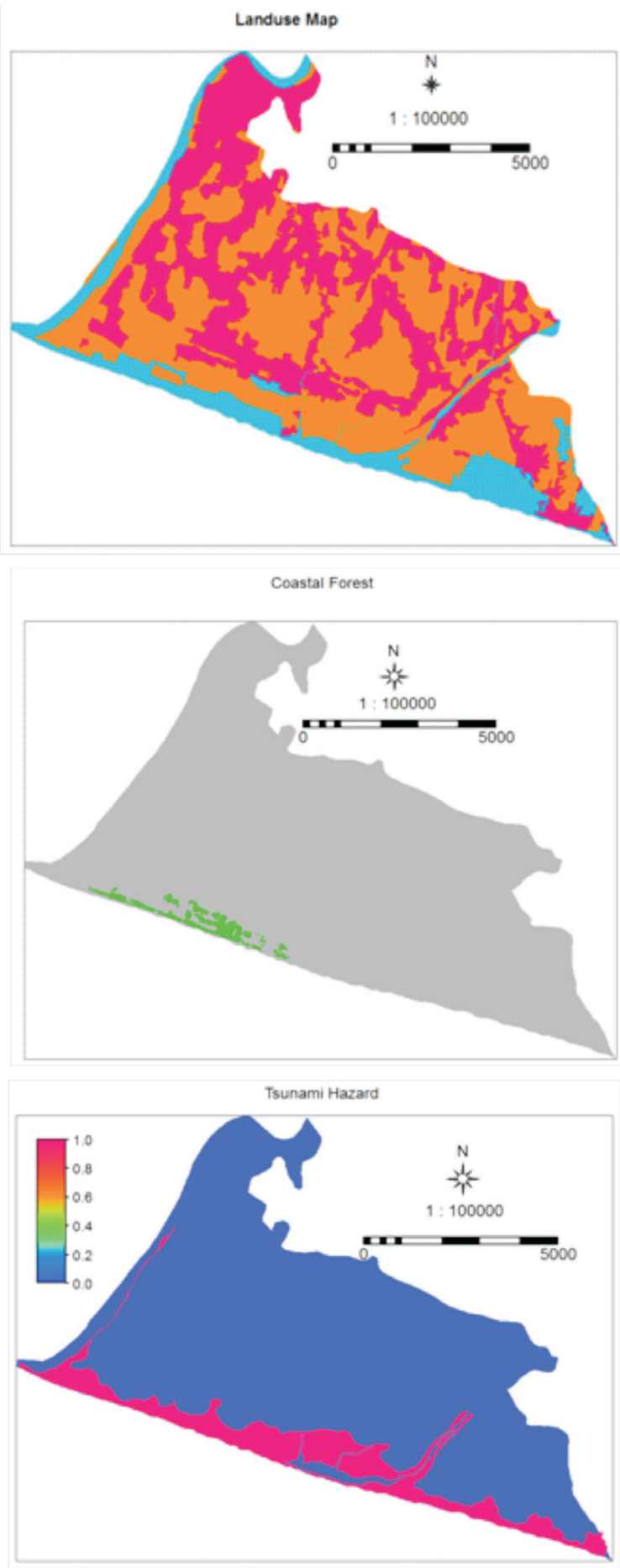

Figure 8. Some ( eospatial \%ata \%eveloped in *wis 4oftware for . acro 4cale. 

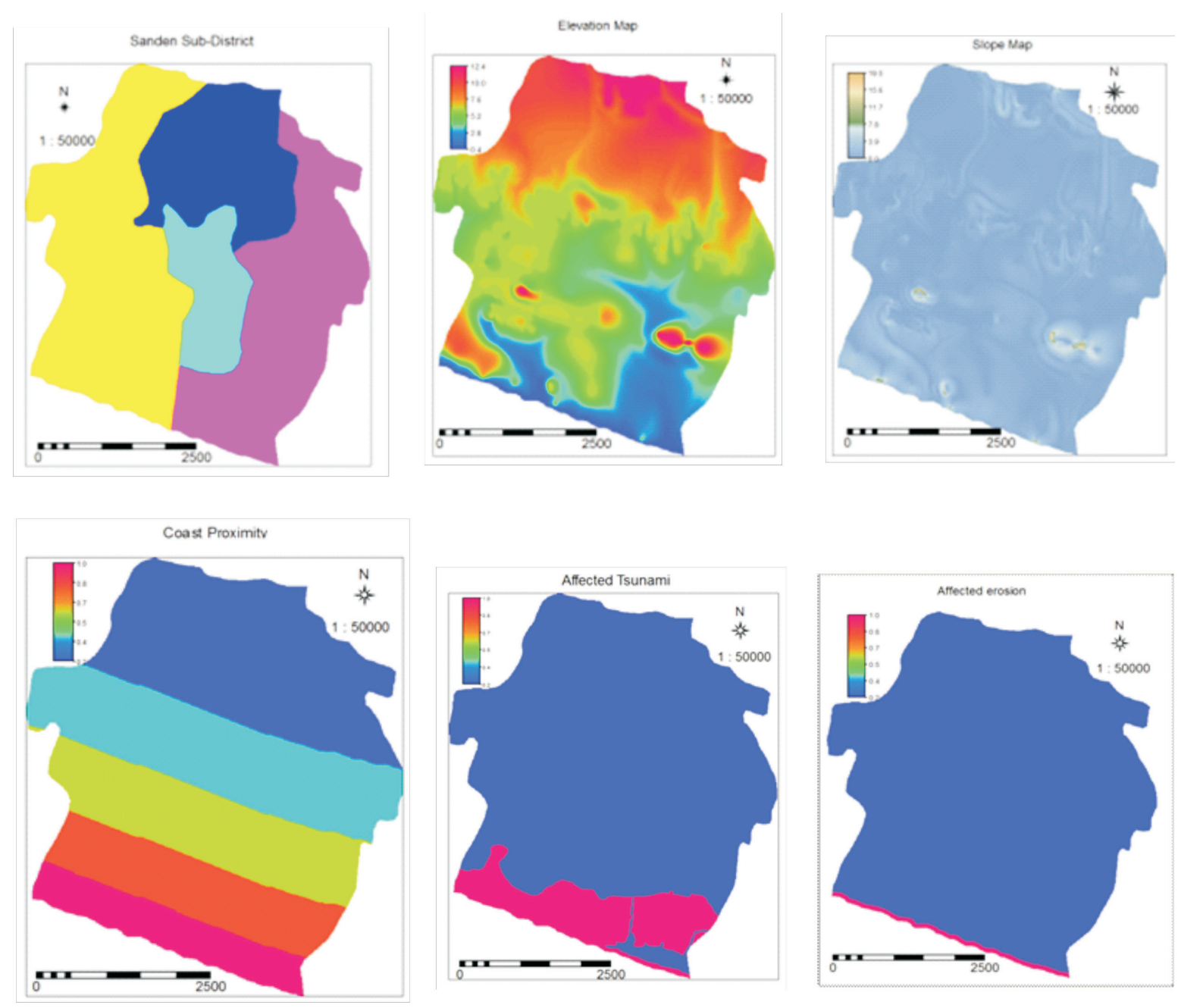

Figure 9. Some Geospatial Data Developed in Ilwis Software for Micro Scale.

the maximum value for ideal setbacks (Figure 13).

Figure 13 describes that the coastal belt wide developed for Sanden Sub-district is wider relatively than other sub-districts (Kretek and Srandakan). The list of maximum and minimum distance of the coastal belt boundary measured landward from the shoreline, by using vulnerability indices outcome generated in the SMCE tool, for macro scale of planning, can be shown in Table 2 .

The coastal vulnerability indices for micro scale were developed by using some improved coastal variables designed for sub-district level of mapping unit. By using the Ilwis-SMCE tool, the coastal vulnerability indices for Sanden Sub-district is given in Figure 14.

In micro scale, the coastal vulnerability indices for Srigading village (bottom-right) higher than three other villages relatively (Figure 14 and Figure 15). However, the village boundary lines seen clearly distinguish between the level of vulnerability due to the use of administrative boundaries as mapping units. In addition, The most area of Sanden is dominated by very highly vulnerable area. The coastal vulnerability indices using pairwise method ranges from 0.27-0.86 and using direct weighting method from $0.27-0.98$, as given in Table 3.

\section{Conclusion}

In the coastal area of Bantul regency, there were 3 (three) main hazards to be reconstucted, i.e. tsunami, highwave and coastal erosion-accretion. The inundated coastal area affected by tsunami hazard was developed by using tsunami hazard map 2012. The highwave affected area was generated by using participatory GIS to reconstruct the highwave as the past disaster event. While, for coastal erosion-accretion was calculated by using short-term shoreline changes method. This study concluded that along coastal area of Bantul regency has affected by both coastal retreating and advancing trends. In the western coast area, coastal accretion was identified by $1.3 \mathrm{~m} /$ year. In contrast, the western coast of Bantul regency affected by coastal erosion of $2.3 \mathrm{~m} /$ year.

In macro scale, the level of coastal vulnerability indices for Bantul regency, in general, is classified as high vulnerable area, with Sanden is the most vulnerable region. In micro scale, the study was focussed on Sanden Sub-district. Srigading village is the most vulnerable 


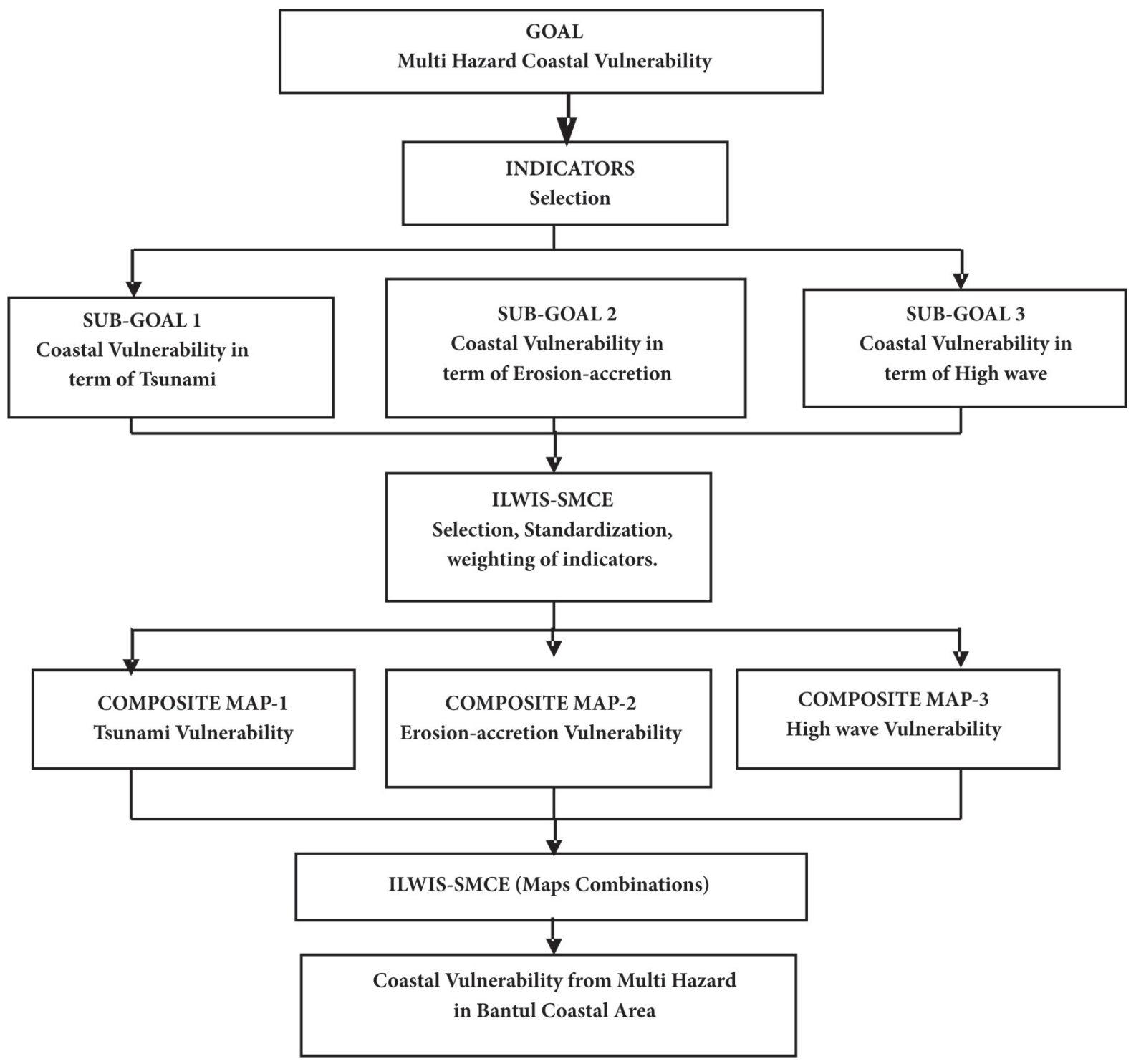

Figure 10. Problem Definitions for Assessing Coastal Vulnerability Indices
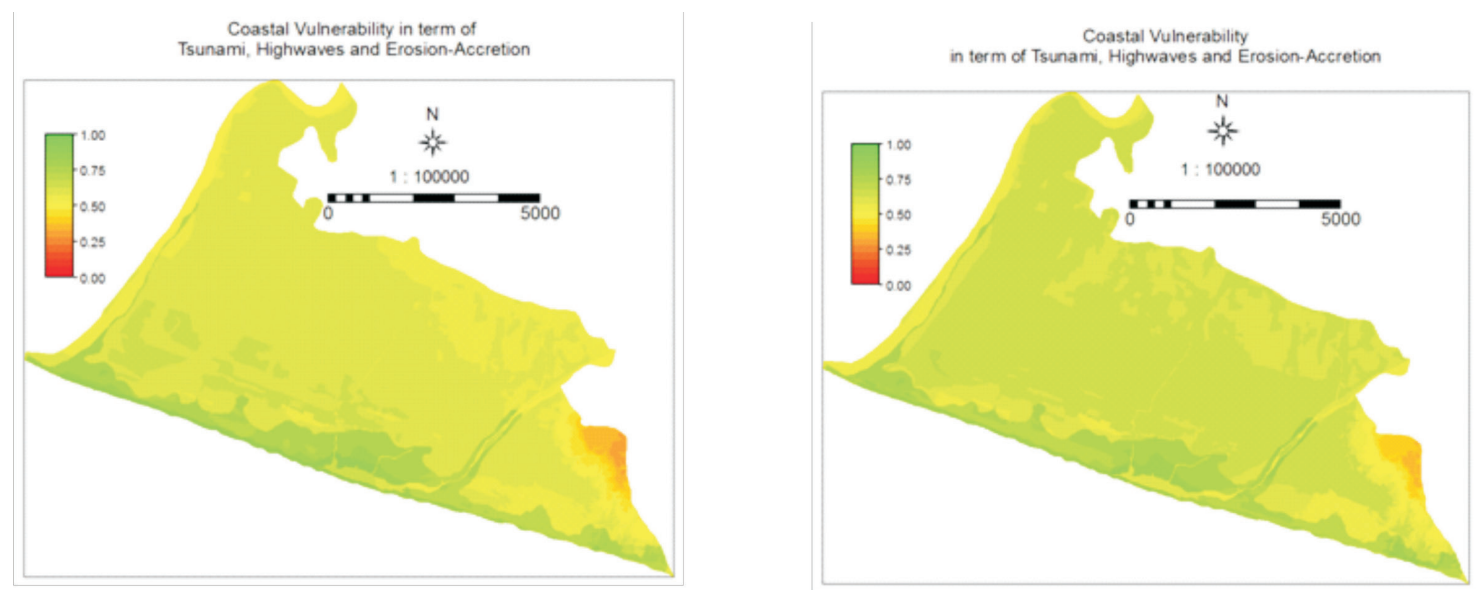

Figure 11. Coastal Vulnerability Indices Maps for the Coastal Area of Bantul Regency using Pairwise (left) and Direct (right) Method. 
area threatened by coastal hazards among other villages in the Sanden sub-district.

In relation with the coastal belt boundary determination, by using ideal scenario in macro scale, minimum setbacks line measured landward from the shoreline show different wide among coastal subdistrict in Bantul, with Sanden as the wider setbaks boundary. In Sanden, minimum distance is counted

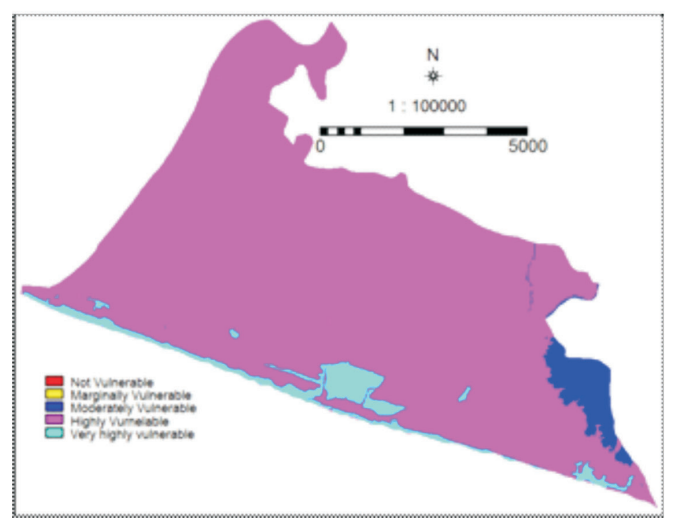

by 326.83 and maximum by $1,213.4 \mathrm{~m} \mathrm{~m}$ measured landward from the shorelines. While, Srandakan subdistrics is the narrowest setbacks wide by maximum of 586.99 and maximum of $137.7 \mathrm{~m}$.

In micro scale, Srigading village requires wider setbacks area than Gadingsari village. In Srigading, by using ideal setbacks scenario, a minimum by 724.8 $\mathrm{m}$ and a maximum by $1.317 \mathrm{~m}$ is required to develop

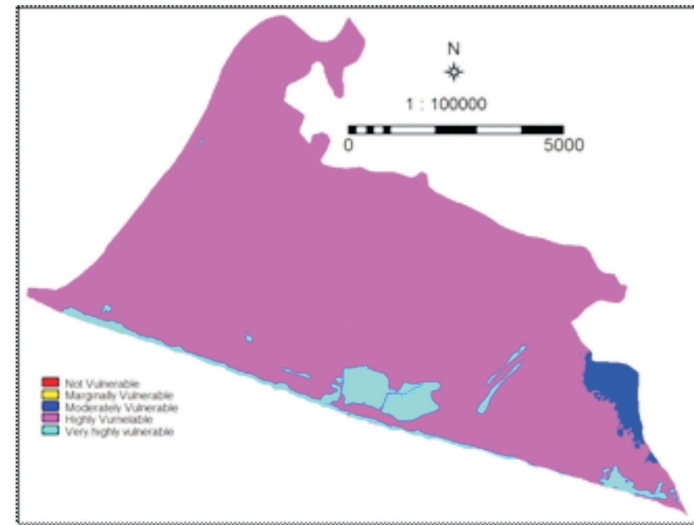

Figure 12. Coastal Vulnerability Indices Maps Using Pairwise (left) and Direct (right) Method using Map Slicing.

Table 1. Coastal Vulnerability Indices for Macro Scale of Bantul Regency

\begin{tabular}{lrrrr}
\hline Pixel Value & Direct & Area & Pairwise & Area \\
\hline Minimum & 0.20 & 600 & 0.16 & 400 \\
Maximum & 0.79 & 15.713 .400 & 0.83 & 12.746 .000 \\
Average & 0.47 & 1.348 .245 & 0.45 & 1.299 .218 \\
Std Dev. & 0.16 & 3.072 .101 & 0.19 & 3.127 .943 \\
\hline
\end{tabular}

Table 2. The scenario of the setbacks wide for the coastal area of Bantul (Pairwise Method)

\begin{tabular}{llrr}
\hline Sub-Districs & \multicolumn{1}{c}{ Scenarios } & $\mathrm{dMax}(\mathrm{m})$ & $\mathrm{dMin}(\mathrm{m})$ \\
\hline Kretek & Ideal & 1084.58 & 116.19 \\
& Moderate & 614.16 & 72.35 \\
& Worst & 332.69 & 24.63 \\
\multirow{5}{*}{ Sanden } & Ideal & 1213.87 & 326.83 \\
& Moderate & 687.37 & 185.07 \\
& Worst & 234.00 & 63.00 \\
\multirow{3}{*}{ Srandakan } & Ideal & 586.99 & 137.69 \\
& Moderate & 332.39 & 77.97 \\
\hline
\end{tabular}

Table 3. The Coastal Vulnerability Indices of Sanden Sub-district

\begin{tabular}{lrrrr}
\hline Pixel Value & Direct & Area & Pairwise & Area \\
\hline Minimum & 0.27 & 100 & 0.27 & 100 \\
Maximum & 0.86 & 1.052 .400 & 0.90 & 843.000 \\
Average & 0.56 & 48.441 & 0.58 & 51.514 \\
Std Dev. & 0.15 & 76.467 & 0.16 & 80.790 \\
\hline
\end{tabular}


The coastal belt boundary map (Pairwise Method)

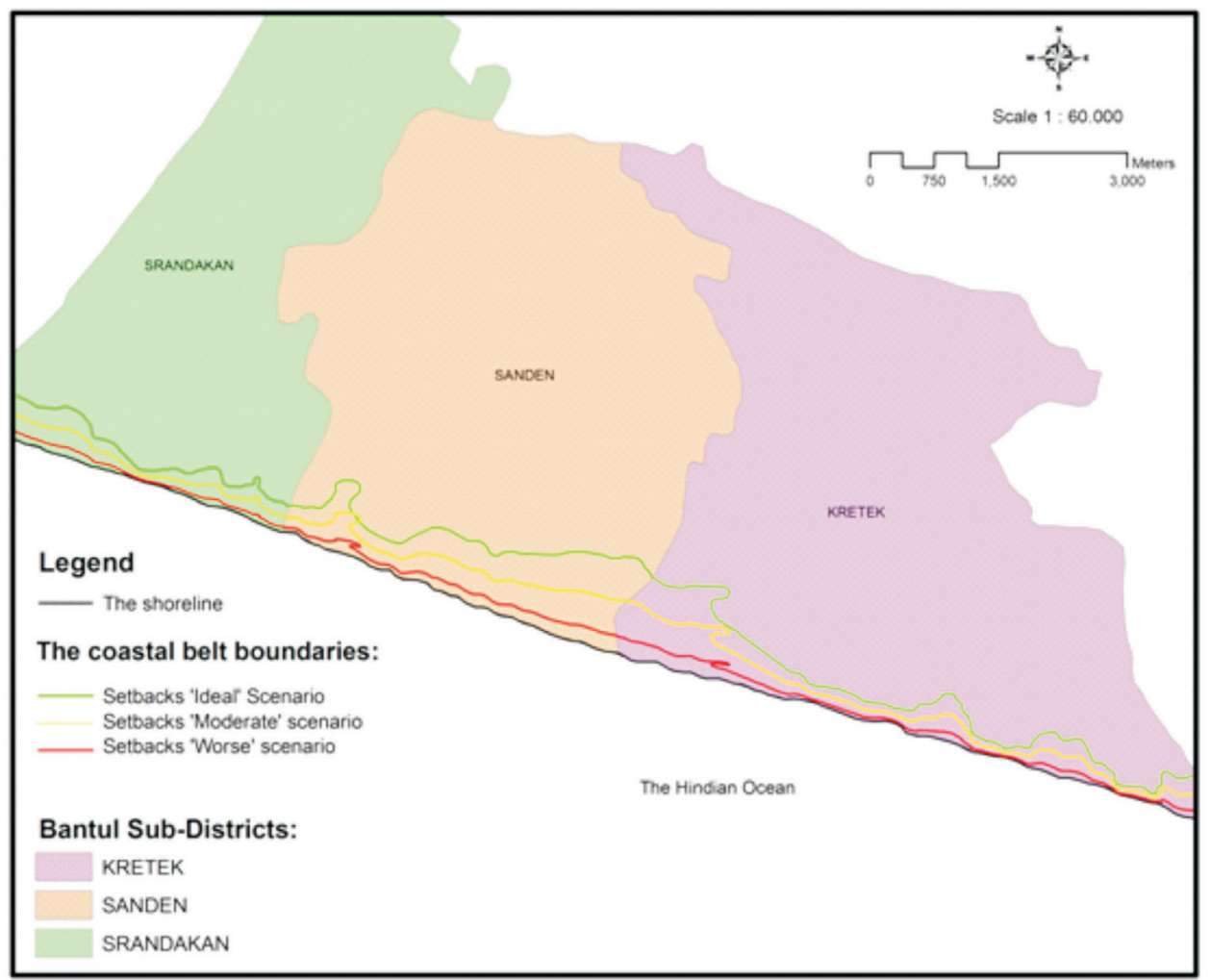

Figure 13. Developed Setbacks Boundary lines in Macro Scale (Pairwise Method)
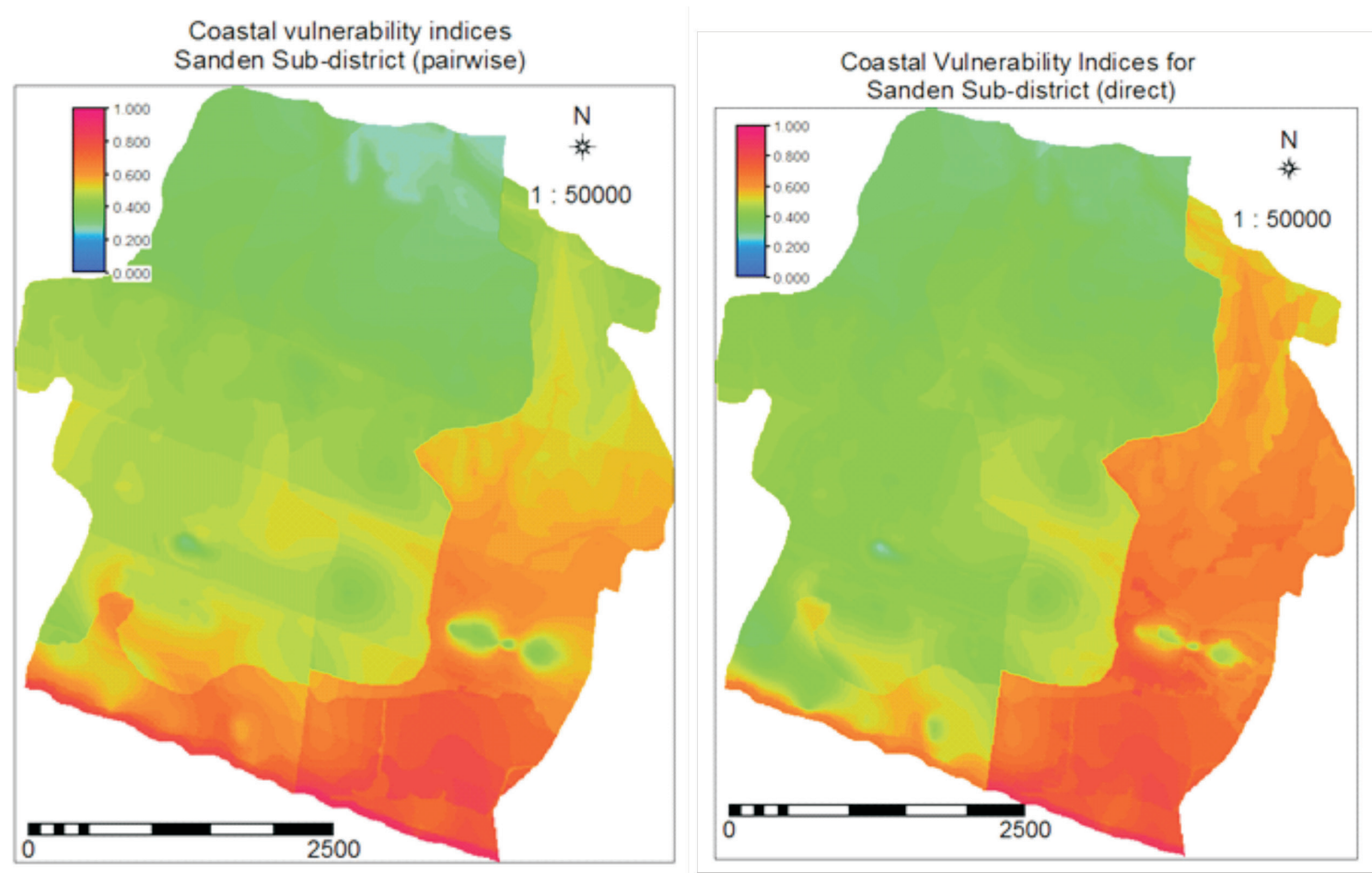

Figure 14. Coastal Vulnerability Indices Maps for the Sanden Sub-district using Pairwise (left) and Direct (right) Method. 

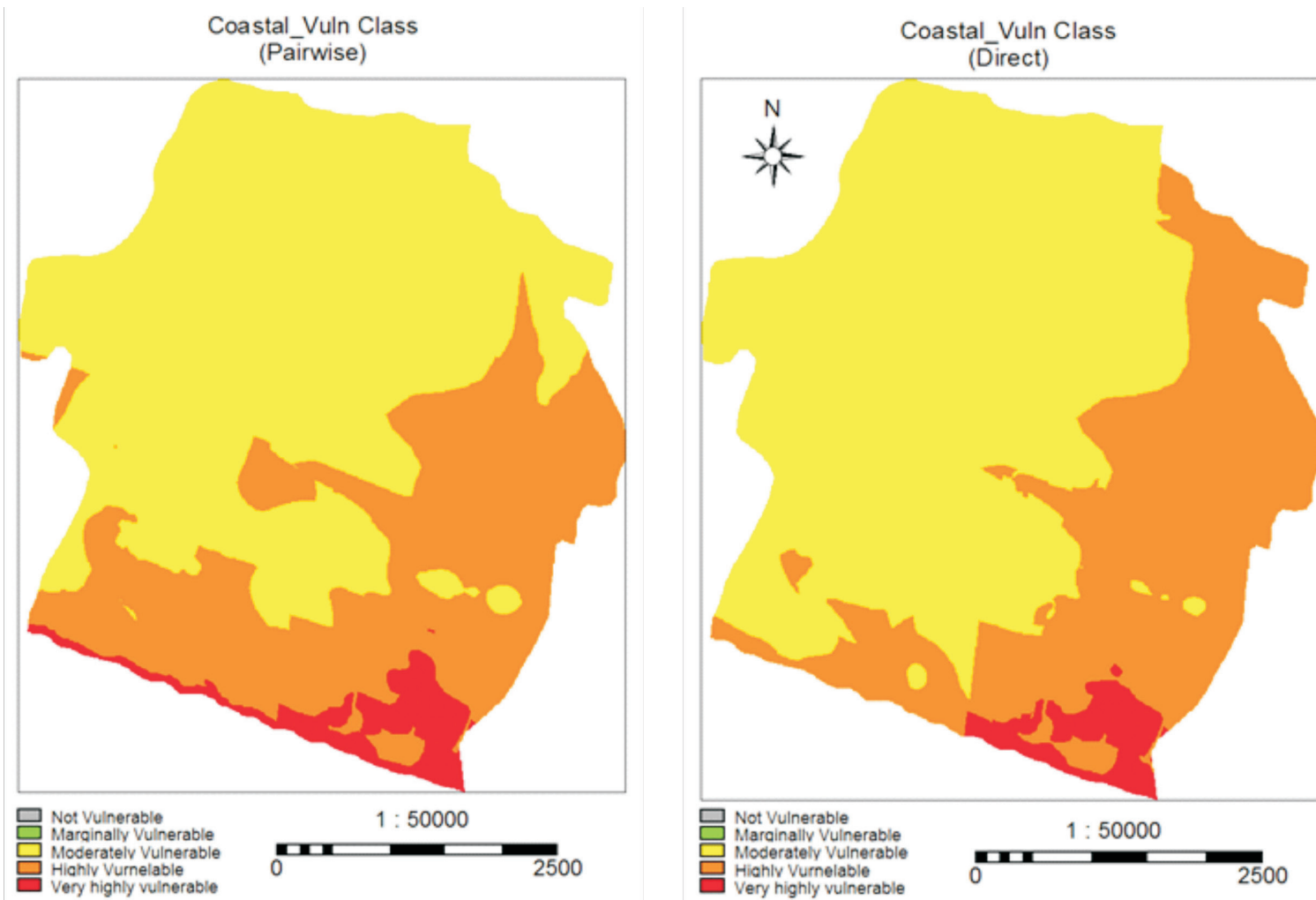

Figure 15. Coastal Vulnerability Indices Maps for Sanden Sub-district using Pairwise (left) and Direct (right) Method using Map Slicing.
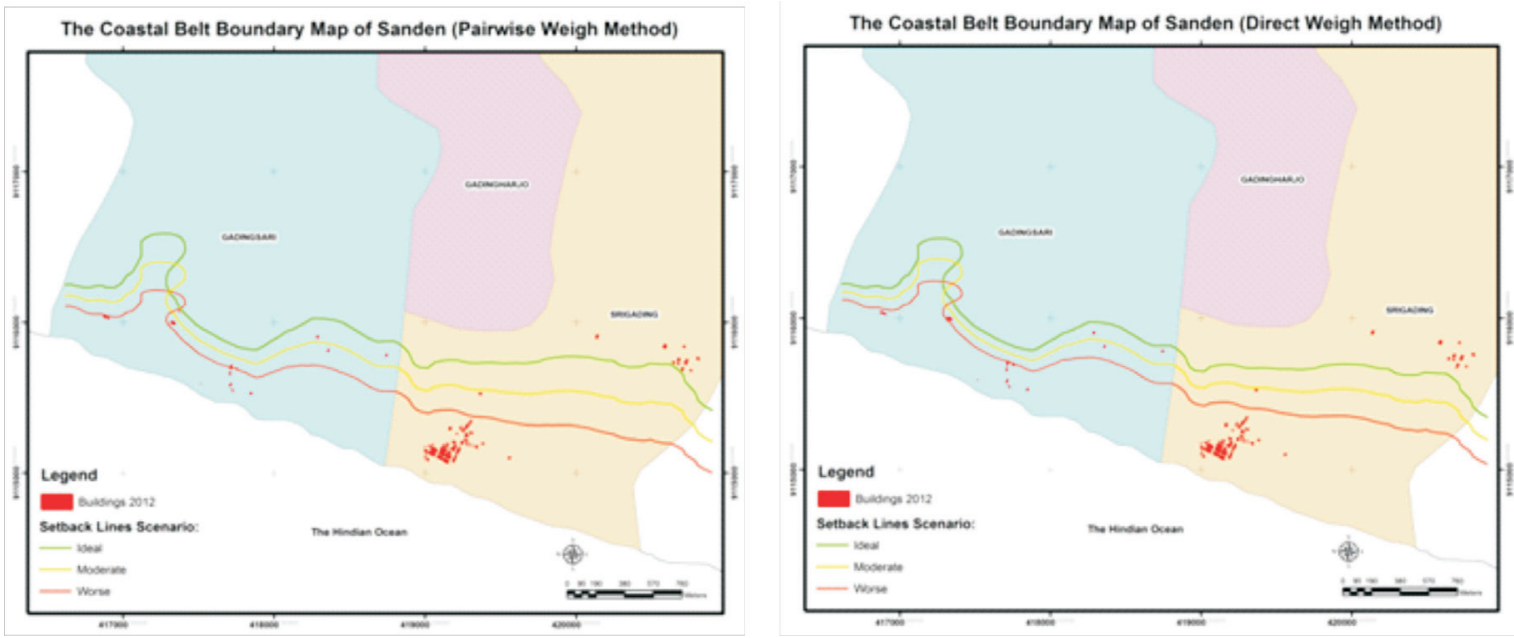

Figure 16. Proposed Setbacks Boundary Maps for Sanden Sub-district

ideal setbacks boundary wide. While, in Gadingsari, minimum and maximum distance of the setbacks boundary was calculated by $352.5 \mathrm{~m}$ and $965.2 \mathrm{~m}$.

Hazard information and coastalvulnerability should be taken into account for determining the coastal belt boundary wide. To identify coastal hazard information, for instance highwave, the use of hazard model should be adressed to obtain more precise inundation area and other hazard characteristics. For the coastal erosionaccretion hazard, it was only used short-term shoreline change and change rate information. By incorporating more remote sensely data types and different method for the shoreline monitoring, the shorelines change and changes rate can be identified accurately.

In term of vulnerability assessment, the quality of input data should be considered by using different criteria and indicator depend on scale of planning. The coastal features used in micro scale should be more detail than those applied in regional - national scale. The next chalenge is how to integrate ecologycal based data and administrative based data. Moreover, detail data in term of shoreline segment is needed for assessing coastal vulnerability in term of coastal erosion-accretion. 
Further research should be develop to reconstruct the proposed method to be tested in other area with different coastal characteristics, different hazards or multi-hazard events as well as in the small islands. Moreover, the zoning regulation applied for each scenario of the setbacks line should be intended as further studies.

\section{References}

Badan Pusat Statistik (2012), Bantul in figures (in bahasa). Bantul Bureau of Statistics, Yogyakarta-Indonesia.

Hizbaron, D. R., Baiquni, M., Sartohadi, J., \& Rijanta, R. (2012), Urban vulnerability in Bantul District, Indonesia-Towards safer and sustainable development. Sustainability 4(9): 2022-2037.

Katsanevakis, S., Stelzenmüller, V., South, A., Sørensen, T. K., Jones, P. J. S., Kerr, S., Hofstede, R. T. (2011), Ecosystem-based marine spatial management: Review of concepts, policies, tools, and critical issues. Ocean \& Coastal Management 54(11): 807-820.

Kongko, W. (2012), Earthquake-Tsunami in Southern Java: potential, model simulation, \& mitigation (in bahasa), Proceeding of Seminar 6 Tahun Refleksi Gempa 27 Mei 2006, Yogyakarta-Indonesia.

Linham, M. M., \& Nicholls, R. J. (2010), Coastal setbacks, http://climatetechwiki.org/content/coastalsetbacks.

Mardiatno, D., Marfai, M. A., \& Sunarto. (2009), Multi-

\section{Acknowledgement}

Thank to Dr. Djati Mardiatno for valuable comments and his support during the research and thanks to review for the constructive comments.

risk of disaster in Parangtritis Coastal Area, Indonesia, Yogyakarta-Indonesia.

Sanò, M., Jiménez, J. A., Medina, R., Stanica, A., Sanchez-Arcilla, A., \& Trumbic, I. (2011), The role of coastal setbacks in the context of coastal erosion and climate change. Ocean \& Coastal Management 54(12): 943-950.

Sutanta, H., Rajabifard, A., \& Bishop, I. D. (2012), Disaster risk reduction using acceptable risk measures for spatial planning. Journal of Environmental Planning and Management 56(6): 761-785.

Thieler, E. R. H., Emily A.; Zichichi, Jessica L.; Ergul, Ayhan. (2009), The Digital Shoreline Analysis System (DSAS) Version 4.0 - An ArcGIS Extension for Calculating Shoreline Change, U.S. Geological Survey.

Westen, C. J. v. e. (2009), Risk City exercise 5b: Overall vulnerability assessment using SMCE for qualitative risk assessment Multi-hazard risk assessment, UNU-ITC School for disaster Geo-Information 